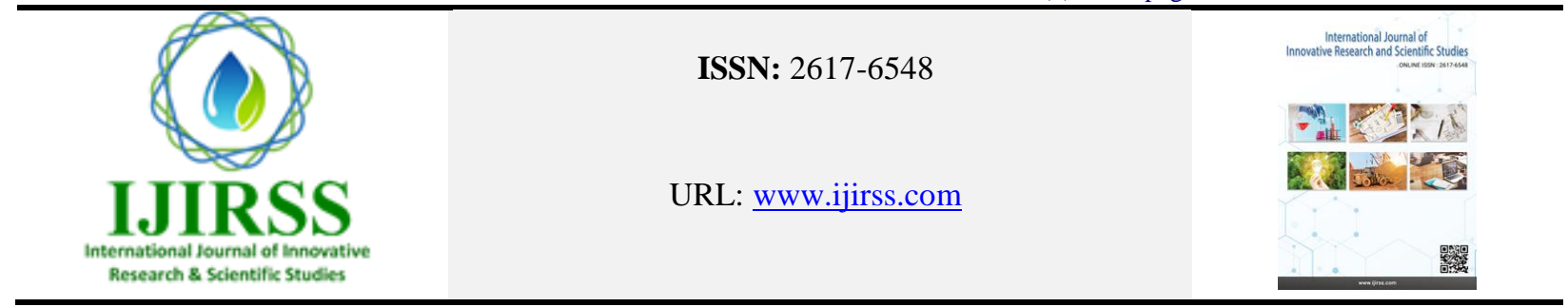

\title{
Determining and Detection of Chemical and Mineral Composition of Gypsum Obtained from Karkar-Doodkas, Baghlan Province
}

\author{
Mohammad Bashir Aimaq ${ }^{1 *}$, Saleh Mohammad Salehy ${ }^{2}$ \\ 1,2 Department of Mining Engineering, Faculty of Engineering, Baghlan University, Baghlan, Afghanistan \\ *Corresponding author: Mohammad Bashir Aimaq (bashiraimaq123@gmail.com)
}

\begin{abstract}
A library and laboratory research experiment was conducted in 2020 on determination and detection of mineralic and chemical appearances of mineralic gypsum in Karkar and Doodkash of Baghlan Province to determine the amount of gypsum minerals in the stones of the areas, detect the composition of gypsum stones and evaluate the importance of gypsum stone in Baghlan Province. The laboratory results indicated that the percentage of mineralic gypsum in composition of mineralic appearances of gypsum stone in Karkar and Doodkash were 95 percent. Despite the slight presence of some other minerals like Sylvine and Iron minerals in composition of the gypsum stone in both the locations were possible. The analyzed laboratory results by XRF machine revealed that besides of the mentioned elements in composition of mineralic appearances of gypsum stone, the elements such as silicon, iron, potassium, chlorine and aluminum were also present in different percentages. Therefore, it can be concluded that the mineralic appearances of gypsum stones in Karkar and Doodkash are the most important gypsum stone in Baghlan province and it can be used for production of constructional gypsum, Ghori Cement Factory and other similar uses.
\end{abstract}

Keywords: Gypsum Stone, Mines, Mineralogy, Chemical Composition.

DOI: $10.53894 /$ ijirss.v3i3.40

Funding: This study received no specific financial support.

History: Received: 27 April 2020/Revised: 3 August 2020/Accepted: 21 August 2020/Published: 2 September 2020

Licensed: This work is licensed under a Creative Commons Attribution 4.0 License $(\mathrm{coc}) \mathrm{EY}$

Acknowledgement: Both authors contributed to the conception and design of the study.

Competing Interests: The authors declare that they have no conflict of interests.

Transparency: The authors confirm that the manuscript is an honest, accurate, and transparent account of the study was reported; that no vital features of the study have been omitted; and that any discrepancies from the study as planned have been explained.

Ethical: This study follows all ethical practices during writing.

\section{Introduction}

Gypsum stone is the hydrous natural calcium sulfate and is found in different crystal form. It is also found in large amount in different forms of the earth layer. The constructional gypsum is obtained by baking and grinding of gypsum stone. In Afghanistan the gypsum stone is found in areas like, Shirin Tagab, Faryab, Orsaj of Takhar, Herat, Badghis, Maidan Wardak, Baghlan and Chardara of Kunduz [1]. The gypsum stone like other stones are composed of different minerals and the minerals are formed from pure elements or combination of different chemical elements. The gypsum stone does not exist in pure form in nature thus the minerals and other chemical elements are present in their composition. The presence and amount of the chemical elements effect on physical and other characteristics of the gypsum stone and are the determinants of the characteristics of the gypsum stone or constructional gypsum. Therefore determination and detection of minerals and chemical elements in composition of the gypsum stone is the most important factors [2]. 
The title of this research which is the determination and detection of mineralic and chemical appearances of mineralic gypsum in Karkar and Doodkash of Baghlan Province, The determination and detection of the mentioned parameters are the most important factors in identification and use of the gypsum stone because all the constructional gypsum which are used in Baghlan and other neighboring provinces are produced from these gypsum stones. Despite this gypsum stone is used in composition of Ghori Cement which is the only cement production factory in Afghanistan. Due to extensive use of KarKar and Doodkash gypsum stones the determination and detection of amount of minerals and chemical elements are necessary. As the objectives of this research are determination of amount of gypsum minerals in gypsum stones of the mentioned areas, detection and determination of chemical elements present in composition of mineralic appearance of Karkar and Doodkash, therefore the successful implementation of this research will solve any vague issues or questions regarding this topic. The research topic which discusses the mineralic composition of mineralic appearances of gypsum stone of Karkar - Doodkash and chemical appearances of mineralic gypsum in Karkar- Doodkash has been supported by reliable references and the findings of laboratory experiment are discussed in details.

\section{Material and Method}

The theoretical part of this research is supported by library research from reliable references and the practical part is implemented by experimental methods. The research has been conducted in 2020 in mineralic area of Karkar-Doodkash located in Pulikhumri district of Baghlan province. Baghlan province is located in north-eastern of Afghanistan and is rich of different mines which gypsum is one the main [3]. Seven samples were collected linearly for laboratory studies from the mentioned area and were transferred to Ghori Cement Factory and to General Directorate of Geological Survey of Ministry of Mines and Petroleum according to sampling procedure.The percentages of mineral gypsum from the samples were identified and determined by Ghori Cement Factory laboratory. The equipment and materials which were used for the chemical analyses of the gypsum samples are chemical acids, different filters, ovens and balance. The presence and percentages of different elements in samples were chemically analyzed with the help of XRF (X-Ray Fluorescence) machine by Directorate of Laboratory of Ministry of Mines and Petroleum.

XRF (X-Ray Fluorescence) device is made to detect chemical elements in the composition of stones, the device works based on the wavelength of chemical elements, this device is one of the advanced tools in detecting and measuring the amount of chemical elements in the composition of stones. The above device performs its activities with excellent capability, high speed, without use of extra chemical and with more accuracy, and has very little environmental effects during operation.

\section{Results and Discussion}

\subsection{Mineralic composition of mineral appearances of gypsum in karkar-Doodkash of Baghlan province}

Gypsum stone like other rocks is composed of different minerals and is one of the sedimentary rocks that occurs in sedimentary basins and aquatic environment [4]. There are large-scale of gypsum mines in Afghanistan, including gypsum mines in Takhar, Balkh, Nangarhar, Samangan and Baghlan provinces [5]. karkar-Doodkash gypsum mine is one of the sedimentary rock mines belonging to the sub-class of salt rocks which the mineral emergence area is shown in Figure 1.

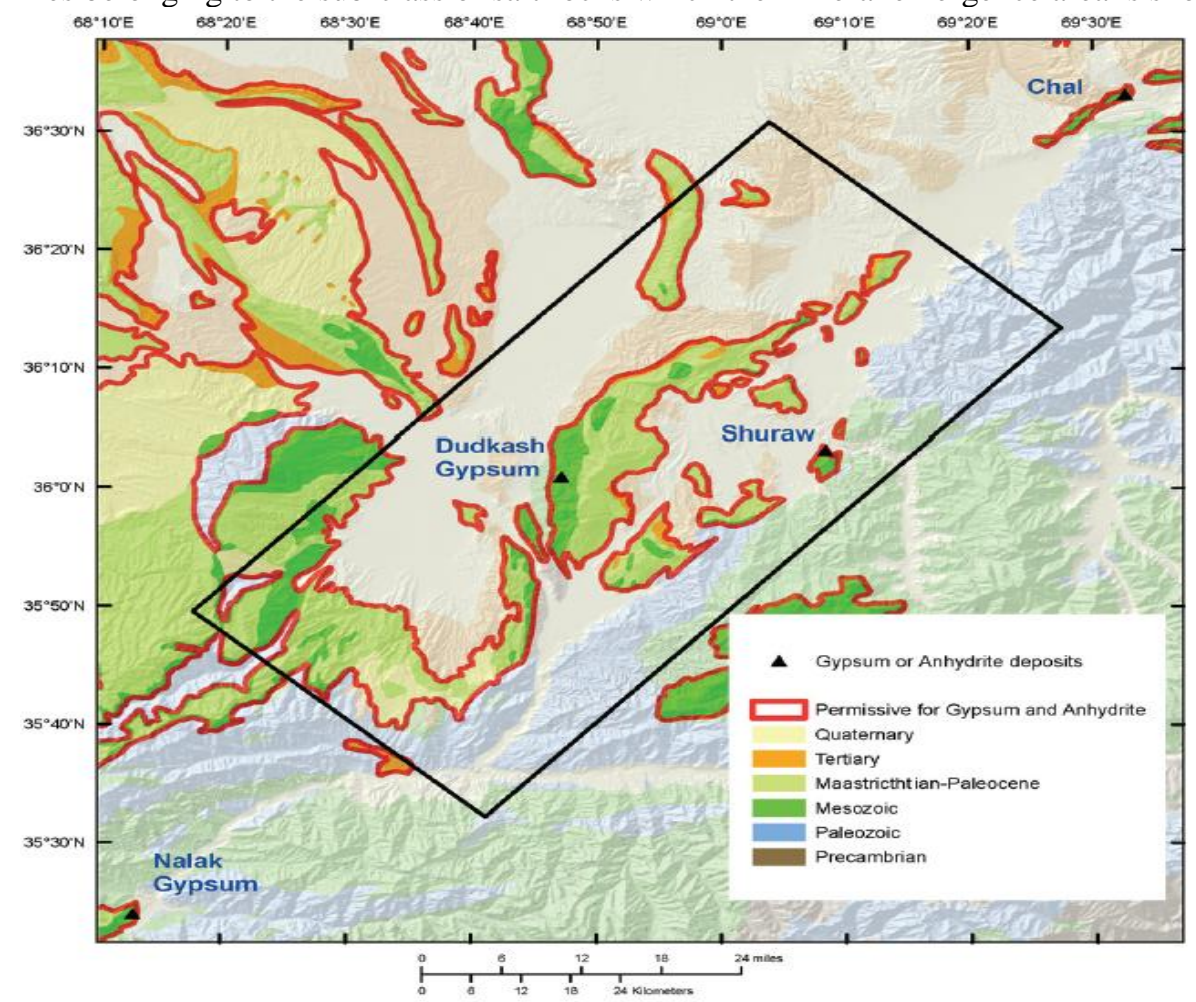

Figure-1.

The Karkar - Doodkash geological area [6]. 
To determine the mineral composition and the percentage of gypsum the samples taken from gypsum of karkarDoodkash mineral appearances have been transferred to Ghori Cement Factory Laboratory located in Pul-e-Khumri city of Baghlan province. The mentioned samples were tested under different operations by common methods in the laboratory and the amounts of gypsum mineral in each of the samples were determined. The characteristics of the samples and the obtained results are presented in Table 1

Table-1.

Laboratory results of determination of mineral gypsum percentage in karkar-Doodkash gypsum stone.

\begin{tabular}{l|l|l|l|l|l}
\hline \multicolumn{4}{l|}{ Sample specifications } & Location & Specified specifications of samples \\
\hline No & Sample name & Province & district & Location & Percentage of mineral plaster \\
\hline 1 & B01 & Baghlan & Pul-e-Khumri & Karkar-Doodkash & 96.30 \\
\hline 2 & B02 & Baghlan & Pul-e-Khumri & Karkar-Doodkash & 97.10 \\
\hline 3 & B03 & Baghlan & Pul-e-Khumri & Karkar-Doodkash & 91.88 \\
\hline
\end{tabular}

Based on the operations performed in the Ghori cement laboratory, it was found each samples (B01, B02 and B03) had different amounts of gypsum mineral in its composition. B01 sample was one of the first samples taken from the study area which had 96.30 percent basic minerals of gypsum and 3.70 percent secondary minerals in its composition.

Sample B02 is the second sample taken from the Karkar-Doodkash mineral area which had 97.10 percent gypsum minerals $97.10 \%$ and 2.90 percent secondary minerals in its composition. B03 sample is the third sample taken from the field in which had $91.88 \%$ gypsum minerals and secondary minerals as $8.12 \%$. The results of the chemical analysis by XRF device revealed that the secondary minerals of gypsum in karkar-Doodkash mineral area contains quartz, magnetite, and sylvine. The laboratory results of three samples of Karkar-Doodkash gypsum (Table 1) indicated that each of these samples had different sizes of gypsum minerals. The results of column in Table 1 clearly indicated that the amount of gypsum minerals in Karkar-Doodkash gypsum is higher than $90 \%$ which the average is $95 \%$.

According to the existing standards in industries, the amount of gypsum minerals in gypsum stones are between 75-95 percent of pure gypsum [7]. Due to the average amount of gypsum minerals (95\%) in Karkar-

Doodkash area, it is considered as pure gypsum. Due to the purity and excellent quality of gypsum minerals in KarkarDoodkash areas, industries as well as constructional companies can use it directly for different constructional purposes without any problem. Currently, Karkar-Doodkash gypsum is used in Ghori Cement Factory for production of cement and also this gypsum is used by several small construction gypsum factories in Baghlan province. Gypsum mines are mostly found in sedimentary basins along with calcite, anhydrite and mud ores [8]. As the results the mineralogical composition of Karkar-Doodkash mineral appearance stone is about $95 \%$ of which $5 \%$ is secondary minerals which are formed in the sedimentary environment at the time of formation. The studies of chemical composition of gypsum minerals indicated that the secondary gypsum minerals of Karkar-Doodkash are quartz, magnetite and sylvine which are belongs oxides and halides class from the mineralogical point of view [9].

\subsection{Chemical composition of Karkar-Doodkash gypsum stone}

Rocks are the natural mineral aggregates formed as the result of geological processes at different depths of the earth [10]. According to the above definition, rocks are composed of the accumulation of minerals that are formed in geological processes, and minerals which are the basic materials of rocks, are composed of pure elements and the composition of chemical elements. For better understanding of the rocks, it is necessary to know its chemical composition. To identify the chemical composition of Karkar-Doodkash gypsum stone, XRF (X-Ray Fluorescence) device of the Ministry of Mines and Petroleum laboratories was used which the result of each sample is presented in separate Tables.

\subsubsection{Sample B01}

The chemical composition of B01 sample in which the complete specifications are listed in Table 2, was analyzed by the XRF device and the results are shown in the table as below.

Table-2.

The composition of chemical sample number B01.

\begin{tabular}{|c|c|c|c|c|c|c|c|c|}
\hline \multicolumn{2}{|l|}{32} & Laboratory No & \multicolumn{2}{|l|}{ gypsum } & Sample & B01 & \multicolumn{2}{|c|}{ Sample No } \\
\hline \multicolumn{9}{|c|}{ Chemical composition percentage $\%$} \\
\hline $\mathrm{Sr}$ & $\mathrm{Fe}$ & $\mathrm{Ca}$ & $\mathrm{Cl}$ & $\mathrm{K}$ & $\mathrm{S}$ & $\mathrm{Si}$ & $\mathrm{Al}$ & Bal \\
\hline 0.15 & 0.13 & 23.21 & 0 & 0.22 & 25.24 & 3.43 & 1.11 & 43.38 \\
\hline
\end{tabular}

The results of chemical analysis of the first sample indicate that Karkar-Dookkash gypsum in addition of basic elements which are calcium, sulfur, oxygen and hydrogen it contains the number of other elements in different sizes in their composition (Table 2). In addition of the basic elements which formed the gypsum mineral, elements such as aluminum, silicon, potassium, chlorine, iron and strontium were also present in small percentages in Karkar-Doodkash gypsum composition.

Bal: has a significant quantity in Table 2, Therefore it is necessary to provide the necessary explanations about it. Bal is the percentage of a set of chemical elements at the top of the Mendeleev table, which are shown by their total XRF 
characteristics under title of Bal. As it can be seen in Table 2, Bal has a significant quantity (43.36 percent), which means that in the composition of the first example, the number of elements are greater at the top of the Table 2. As in the upper part of Mendeleev table, elements such as hydrogen, helium, oxygen, sodium, lithium, etc. have taken place. Since oxygen is one of the basic constituents of gypsum mineral, the presence of oxygen has an important role in increasing the quantity of Bal.

\subsubsection{Sample B02}

This sample is also taken from the gypsum of the Karkar-Doodkash mineral area. The sample was chemically analyzed by XRF device and the results of its specifications are listed in Table 3.

Table-3.

The chemical composition of samples number B02.

32
\begin{tabular}{l|l|l|l|l|l|l|l|l}
\hline Laboratory No & Gypsum & Sample & B02 & Sample No \\
\hline Chemical composition percentage \% & $\mathrm{K}$ & $\mathrm{Cl}$ & $\mathrm{K}$ & $\mathrm{S}$ & $\mathrm{Si}$ & $\mathrm{Al}$ & $\mathrm{Bal}$ \\
\hline $\mathrm{Sr}$ & $\mathrm{Fe}$ & $\mathrm{Ca}$ & 0.11 & 0.15 & 29.58 & 2.28 & 0.62 & 42.36 \\
\hline 0 & 0 & 24.73 &
\end{tabular}

If you look at the results of B02 sample, it can be clearly seen that in the composition of this stone, the elements of aluminum, silicon, potassium, chlorine are present in different quantities and Bal is also present in sufficient quantity. As the presence of potassium and chlorine in this sample indicates a sedimentary environment, therefore it is possible that potassium salt is also formed in the mentioned environment. As the quantity of elements such as strontium and iron in sample B02 is equal to zero therefore it shows that the absence of these elements in the composition of the sample.

\subsubsection{Sample B03}

This sample was also taken from the Karkar-Doodkash mineral area. The laboratory results of this sample performed by XRF device shows the following specifications presented in Table 4.

Table-4.

The chemical composition of samples number B03.

\begin{tabular}{l|l|l|l|l|l|l|l|l}
\hline $\mathbf{3 2}$ & Laboratory No & Gypsum & Sample & B03 & Sample No \\
\hline Chemical composition percentage \% & $\mathrm{Ca}$ & $\mathrm{Cl}$ & $\mathrm{K}$ & $\mathrm{S}$ & $\mathrm{Si}$ & $\mathrm{Al}$ & $\mathrm{Bal}$ \\
\hline $\mathrm{Sr}$ & $\mathrm{Fe}$ & $\mathrm{Cl}$ & 0.14 & 0.18 & 29.40 & 2.71 & 1.01 & 42.38 \\
\hline 0 & 0 & 23.97 &
\end{tabular}

The chemical composition in this sample is similar to the second or previous sample, but the quantities of some of the basic and secondary elements that make the gypsum differ from each other according to the geological conditions of formation which the differences can be clearly seen by comparing both the Tables.

\subsubsection{Sample B04}

The following sample is also taken from the gypsum of the Karkar-Doodkash mineral area and is tested under necessary operations in the laboratory. As the result its chemical composition has been identified and determined (Table 5).

Table-5.

The chemical composition of samples number B04.

\begin{tabular}{|c|c|c|c|c|c|c|c|c|}
\hline \multicolumn{2}{|l|}{32} & Laboratory No & \multicolumn{2}{|l|}{ Gypsum } & Sample & B04 & \multicolumn{2}{|c|}{ Sample No } \\
\hline \multicolumn{9}{|c|}{ Chemical composition percentage $\%$} \\
\hline $\mathrm{Sr}$ & $\mathrm{Fe}$ & $\mathrm{Ca}$ & $\mathrm{Cl}$ & $\mathrm{K}$ & $\mathrm{S}$ & $\mathrm{Si}$ & $\mathrm{Al}$ & Bal \\
\hline 0.14 & 0.15 & 24.95 & 0.14 & 0.25 & 30.83 & 3.10 & 1.17 & 39.18 \\
\hline
\end{tabular}

As can be seen in the sample, in addition to the basic constituent elements of gypsum, elements such as silicon and iron, potassium, chlorine and strontium are also seen which these elements unite with each other to form different minerals. Also, the presence of secondary elements and minerals in the composition of Karkar-Doodkash gypsum has different effects on the physical and chemical properties of gypsum mineral. For example, the presence of silicon elements causes hardness and light color in gypsum. Also, the presence of iron indicates iron minerals in the gypsum composition of the mentioned area. The presence of iron and its minerals has caused a dark, yellowish color in gypsum and also has extraordinary effects on the other properties of the stone.

The findings of the chemical analysis of Karkar-Doodkash gypsum mineral appearance indicate some other important facts that are discussed as below. Certainly gypsum is formed by gypsum minerals and a number of other minerals. Gypsum minerals are chemically composed of elements such as calcium, sulfur, oxygen and hydrogen. The findings and results of laboratory analysis of gypsum of Karkar-Doodkash mineral area by XRF machine indicates that besides the basic 
elements of gypsum minerals other elements such as aluminum with more than $1 \%$, silicon with about $3 \%$ and a little amount of Iron, percentium, potassium and chlorine are present in gypsum stone of the mentioned area. Due to above findings it can be concluded that in the above sedimentary basin in addition of the gypsum minerals in mineral composition of gypsum, the halides class of minerals and minerals of the class of oxides, especially iron and quartz minerals are present in different and low percentages. On the other hand, from the qualitative point of view the existence of the mentioned minerals are not harmful where they are used besides it may also improve the quality of the produced cement and constructional gypsum. Since the gypsum origination is related to the sedimentary rocks of the sub-class of salt, therefore the existence of different slats in composition of the mentioned rocks are possible [11].

\section{Conclusion}

Karkar-Doodkash mineral appearance gypsum stones are one of the best gypsum stones in Baghlan province, because the amounts of gypsum minerals in the composition of the mentioned stones are $95 \%$ as average. Also in addition of minerals gypsum the regional sedimentary minerals such as selenium, quartz, iron minerals, etc. are present composition of Karkar-Doodkash gypsum stone. The mineralic area of Karkar-Doodkash gypsum stone in addition to the constituent elements of gypsum such as calcium, sulfur, oxygen and hydrogen it has some other chemical elements such as aluminum, silicon, potassium, chlorine, iron and some other elements of Mendeleev's table in its chemical composition. Due to higher percentage of gypsum minerals $(95 \%)$ of Karkar-Doodkash area, it is suitable for production of constructional gypsum and use for production of Ghori cement. Therefore, the Karkar-Doodkash gypsum stones are one of the most important and valuable sources for the production of constructional gypsum and other similar uses.

\section{References}

[1] S. Mansori, "Mining watch Afghanistan. Retrieved from https://mwafghanistan.blogspot.com," 2016.

[2] N. Sahak, Mineral in Afghanistan, Afghanistan geological survey. Kabul, Afghanistan: PMU Directorate, 2014.

[3] A. S. Mohammad, General geography of provinces in Afghanistan. Kabul: First, Sarwer Saddat, 2015.

[4] I. K. Whitbread, Petrography. In: Gilbert A.S. (Eds), Encyclopedia of Geoarchaeology. Encyclopedia of Earth Sciences Series. Dordrecht: Springer, 2017.

[5] M. A. Zaki, Mines contract challenges. Kabul: First Nashr-e-Waza, 2015.

[6] J. L. Doebrich, R. R. Wahl, S. D. Ludington, P. G. Chirico, C. J. Wandrey, R. G. Bohannon, G. J. Orris, J. D. Bliss, A. Wasy, and M. O. Younusi, "Geologic and mineral resource map of Afghanistan: U.S," Geological Survey Open File Report2006.

[7] N. Bihzadi and J. Moqadm, Hasnzada Goji. Sanabad, Tehran: Plaster Engineering, 2012.

[8] Y. Selavin, "General geology in Afghanistan bassic geology, Mir, Mosscow. Retrileved from https://urss.ru.com," 2015.

[9] G. Khupolwak, "Mineralogy first soratgar, Mazar-e-Sharif," 2016.

[10] N. Sahak, Stones in Afghanistan, Afghanistan geological survey. Kabul: New Mustaqbel, 2015.

[11] M. H. Gerzyvani, The science of mines. Tehran: Third, Semat, 2016. 